\title{
BEBERAPA FAKTOR YANG MEMPENGARUHI PRICE EARNINGS RATIO STUDI PADA PERUSAHAAN-PERUSAHAAN MANUFAKTUR YANG TELAH GO-PUBLIC DI BURSA EFEK INDONESIA
}

\author{
Drs. Saut Purba, MM
}

\begin{abstract}
This study aims: First, to get the variables that affect the price earnings ratio. Second, to obtain empirical evidence about the impact of these variables on price earnings ratio.

To achieve this purpose, research on companies listed on the Indonesia Stock Exchange at the end of 2013. The number of companies manufacturing the research samples as many as 98 companies. By using eight regression model to explain the determinants of price-earnings ratio is obtained the following results.

First, return on equity, the expected yield or capitalization rate, growth, dividend payout ratio, total asset turnover, net profit margin, and the debt to equity ratio is a determinant of price-earnings ratio. Second, the return on equity have a positive influence and significant impact on the price earnings ratio, expected returns or the capitalization rate affects negatively and significantly influence on the price earnings ratio, growth positive influence and significant impact on the price earnings ratio, dividend payout ratio positive effect and significant to price earnings ratio, total asset turnover and significant positive effect on the price-earnings ratio, net profit margin and significant positive effect on the priceearnings ratio, and debt to equity ratio and significant positive effect on the price earnings ratio. Third, the debt to equity ratio is the dominant determinant of the price earnings ratio. Fourth, the price earnings ratio variation able to be explained by variations in the independent variables of 43.1 to 75.6 percent.

It may therefore be argued that this study is useful for: First, to provide information to investors about the variables that need to be considered when investing in the stock market and affect the price earnings ratio. These variables are the retention ratio, dividend payout ratio, total asset turnover, net profit margin, debt to equity ratio, the required yield, growth, and return on equity. Second, add a reference to the capital market in relation to fundamental factors. Third, the results of this study are expected to be a reference to the head of the company in order to increase the value of the company.

Key Words: Price Earnings Ratio, Fundamental Approach, Capital Market
\end{abstract}

\section{PENDAHULUAN}

Pasar modal Indonesia mulai berkembang setelah pemerintah mengeluarkan berbagai paket kebijaksanaan. Paket kebijaksanaan tersebut dimulai dengan Pakdes 1987, Pakto 1988, dan paket kebijaksanaan lainnya. Pada dasarnya Paket kebijaksanaan tersebut berisi usahausaha untuk menggairahkan pasar modal Indonesia agar pasar modal berperan dalam membiayai dunia usaha dan juga sebagai media investasi yang kompetitif dengan lembaga keuangan lainnya.

Dalam kurun waktu selama 36 tahun, semenjak dikeluarkannya Pakdes 1987, perusahaan-perusahaan yang telah mengemisikan sahammnya di pasar modal Indonesia menunjukkan peningkatan yang pantastis, dari 24 perusahaan tahun 1987 menjadi 435 perusahaan tahun 2013. Fenomena ini dapat dimaknai semakin bertambahnya perusahaanperusahaan di Indonesia yang memanfaatkan pasar modal sebagai sumber pembiayaan atas hartanya.

Perkembangan pasar modal, di samping semakin banyaknya anggota bursa, juga dapat dilihat dari perubahan harga-harga saham yang diperdagangkan. Perubahan harga saham tersebut dapat memberi petunjuk tentang kegairahan dan kelesuan aktivitas perdagangan di pasar modal. Memang begitulah adanya bahwa harga saham bisa naik dan bisa turun. Oleh 
karena itu, suatu hal yang perlu dipertanyakan adalah variabel-variabel apa saja yang mempengaruhi naik turunnya harga saham tersebut?

Dalam kaitannya dengan harga saham, Francis (1988) mengemukakan dua pendekatan dalam penilaian saham, yakni: the technical approach dan the fundamental approach. Pendekatan teknikal memusatkan perhatiannya pada charts harga saham sehingga sering disebut sebagai chartists. Teknik analisis yang bersifat teknikal lebih menekankan pada perilaku harga saham, volume perdagangan saham serta keuntungan modal. Aliran ini menyatakan bahwa pemodal pada dasarnya adalah irrasional. Pendekatan fundamental merupakan metode yang lebih popular dalam mengestimasi nilai saham. Dalam mengestimasi nilai sekuritas, analis fundamental mempelajari analisis ekonomi, analisis industri, dan analisis perusahaan (Amling: 1989).

Mengingat kedua pendekatan tersebut saling kontradiktif, akan tetapi saling melengkapi dalam penilaian suatu saham, dan penelitian ini difokuskan pada pendekatan fundamental dalam menilai saham.

Beberapa penelitian yang berhubungan dengan faktor-faktor yang mempengaruhi harga saham di Pasar Modal Indonesia telah banyak dilakukan. Silalahi (1992) menemukan bahwa harga saham secara serentak dipengaruhi oleh rate of return on total assets, dividend payout ratio, financial leverage, volume perdagangan saham, dan tingkat suku bunga deposito. Lebih lanjut, Sihombing (2008) menemukan bahwa return on equity, debt to equity ratio, net book value, dividend payout ratio, dividend growth, dan tingkat keuntungan yang disyaratkan investor merupakan faktor-faktor fundamental yang mempengaruhi harga saham.

Berdasarkan penelitian-penelitian tersebut di atas, penelitian ini difokuskan pada pengaruh beberapa faktor terhadap price earning ratio. Penelitian ini berbeda dengan penelitian terdahulu, karena variabel dependen dan kondisi ekonomi relatif berbeda. Informasi tentang faktor-faktor fundamental yang menpengaruhi harga saham juga dipergunakan, hanya saja dalam penelitian ini, penentuan variabel- variabel fundamental dalam kaitannya dengan price earnings ratio didapatkan berdasarkan pengembangan suatu model.

Dengan berpedoman pada paparan tersebut di atas, maka penelitian ini bertujuan untuk: Pertama, mendapatkan variabel-variabel yang mempengaruhi price earnings ratio. Variabel-variabel tersebut adalah retention ratio, dividend payout ratio, total assets turnover, net profit margin, debt to equity ratio, imbal hasil yang disyaratkan, pertumbuhan perusahan, dan return on equity. Kedua, mendapatkan bukti empiris tentang dampak retention ratio, dividend payout ratio, total assets turnover, net profit margin, debt to equity ratio, imbal hasil yang disyaratkan, pertumbuhan perusahan, dan return on equity.terhadap price earnings ratio.

\section{Pendekatan Penilaian Saham}

\section{TINJAUAN PUSTAKA}

Pasar modal pada hakekatnya merupakan suatu kegiatan yang mempertemukan pihak penjual dan pembeli dana. Dana yang diperjualbelikan itu dipergunakan untuk tujuan jangka panjang demi pengembangan usaha. Oleh karenanya, dana yang diperoleh serta pengalokasiannya pada berbagai bentuk penggunaan harus dilakukan secara efisien dan efektif guna memaksimumkan nilai perusahaan.

Francis (1988) mengemukakan dua pendekatan dalam penilaian saham, yakni: the technical approach dan the fundamental approach. Analis keuangan sering mempergunakan teknik yang berbeda untuk mengestimasi nilai saham. Pendekatan teknikal memusatkan perhatiannya pada charts harga saham sehingga sering disebut sebagai chartists. Teknik analisis yang bersifat 
teknikal lebih menekankan pada perilaku harga saham, volume perdagangan saham serta keuntungan modal. Aliran ini menyatakan bahwa pemodal pada dasarnya adalah irrasional.

Bursa pada dasarnya adalah cerminan tingkah laku masyarakat pemodal. Seorang individu yang bergabung kedalam suatu massa, bukan sekedar kehilangan rasionalitasnya tapi juga sering melebur identitas pribadinya ke dalam identitas kolektif. Aliran ini juga percaya bahwa trend harga saham akan terjadi secara berulang. Di sisi lain, nilai saham ditentukan oleh kekuatan permintaan dan penawaran saham dan aliran ini juga mengabaikan nilai intrinsic.

Pendekatan fundamental merupakan suatu metode yang lebih popular dalam mengestimasi nilai saham. Dalam mengestimasi nilai sekuritas, analis fundamental mempelajari analisis ekonomi, analisis industri, dan analisis perusahaan (Amling: 1989).

\section{Determinan Price Earnings Ratio}

Menurut Weston dan Copeland (1986) bahwa harga sekarang $\left(\mathrm{P}_{0}\right)$ dari suatu saham tergantung dari seberapa besar tingkat keuntungan yang diharapkan pemodal bila membeli saham, dan seberapa besar tingkat risiko arus kas yang diharapkan. Keuntungan yang diharapkan terdiri dari: (1) dividen yang diharapkan setiap tahun $\left(D_{t}\right)$, dan (2) harga saham yang diterima pemodal jika saham yang dimiliki dijual kembali pada akhir tahun ke-n $\left(\mathrm{P}_{\mathrm{n}}\right)$, dan untuk menghitung nilai sekarang dari arus kas tersebut dapat dipergunakan biaya modal sendiri atau tingkat keuntungan yang disyaratkan oleh investor $\left(\mathrm{K}_{\mathrm{e}}\right)$.

Berdasarkan pengertian tersebut, dan secara matematis, bila investor menyimpan saham dalam jangka waktu satu tahun, maka konsep di atas dapat dimodelkan menjadi:

$\mathrm{P}_{0}=\left(\mathrm{D}_{1}+\mathrm{P}_{1}\right) /\left(1+\mathrm{K}_{\mathrm{e}}\right)$

Untuk mempermudah estimasi harga saham, model (1) dapat disederhanakan dengan asumsi: (1) perusahaan mengalami pertumbuhan yang konstan atas laba atau dividen sebesar g persen per tahun, dan (2) pemodal menyimpan saham dalam waktu yang tidak terbatas. Dengan memperhatikan asumsi tersebut, maka model (1) berubah menjadi:

$\mathrm{P}_{0}=\mathrm{D}_{1} /\left(\mathrm{K}_{\mathrm{e}}-\mathrm{g}\right)$

Model tersebut dapat diimplementasikan dengan suatu asumsi bahwa imbal hasil yang disyaratkan atau biaya modal sendiri $\left(\mathrm{K}_{\mathrm{e}}\right)$ harus lebih besar daripada tingkat pertumbuhan perusahaan (g). Lebih lanjut, berdasarkan model tersebut dapat dikemukakan bahwa harga saham akan mengalami perubahan dengan berubahnya dividen, imbal hasil yang disyaratkan, dan pertumbuhan dividen.

Misalkan saja pada tahun pertama, laba per lembar saham (E) sebagian dibayarkan kepada para pemegang saham dalam bentuk dividen (D) serta sebagian lagi diinvestasikan dalam perusahaan atau ditahan $(b)$, sehingga besarnya dividen pada tahun pertama $\left(\mathrm{D}_{1}\right)$ adalah $: \mathrm{D}_{1}=(1-\mathrm{b}) \mathrm{E}$ dimana: $\mathrm{E}_{1}=\mathrm{E}_{0}(1+\mathrm{g})$ serta tingkat pertumbuhan laba/dividen merupakan perkalian antara proporsi laba ditahan (b) dengan tingkat keuntungan penginvestasian kembali (R) atau $\mathrm{g}=\mathrm{bR}$. Oleh karena itu, model (2) dapat dirubah menjadi:

$P_{0}=(1+b R)(1-b) E_{0} /\left(K_{e}-b R\right)$.

Dengan membagi pendapatan per lembar saham $\left(\mathrm{E}_{0}\right)$ kepada persamaan (3), maka model baru menjadi :

$$
\mathrm{P}_{0} / \mathrm{E}_{0}=(1-\mathrm{b})(1+\mathrm{bR}) /\left(\mathrm{K}_{\mathrm{e}}-\mathrm{bR}\right)
$$

Dengan demikian, berdasarkan persamaan 4, variabel-variabel yang membentuk price earnings ratio $(\mathrm{P} / \mathrm{E})$ adalah proporsi laba ditahan (b), Tingkat keuntungan penginvestasian kembali laba ditahan (R), dan biaya modal sendiri atau imbal hasil yang disyaratkan investor $\left(\mathrm{K}_{\mathrm{e}}\right)$.

Tingkat pertumbuhan laba atau dividen (g) dapat juga diperoleh dengan mengalikan return on equity (ROE) dengan retention rate (b), atau dirumuskan sebagai berikut: $g=R O E x b$. Oleh karenanya, model (4) dapat juga dirubah menjadi: 
$\mathrm{P}_{0} / \mathrm{E}_{0}=(1-\mathrm{b})(1+\mathrm{ROE}) /\left(\mathrm{K}_{\mathrm{e}}-\mathrm{bR}\right)$

Berdasarkan persamaan (5) dapat dikemukakan bahwa price earnings ratio dipengaruhi oleh retention ratio (b), return on equity (ROE), imbal hasil yang disyaratkan (Ke), dan pertumbuhan perusahaan $(\mathrm{g})$.

Selanjutnya, dengan mempergunakan model dupon yang telah dimodifikasi bahwa return on equity (ROE) merupakan perkalian antara return on assets (ROA) dengan equity multiplier (EM), sedangkan return on assets (ROA) merupakan perkalian antara total assets turnover (TAT) dengan net profit margin (NPM) sehingga return on equity (ROE) dapat ditentukan sebagai berikut:

ROE $=$ TAT $\times$ NPM $(1+\mathrm{D} / \mathrm{E})$

Dengan mensubsitusikan persamaan (6) terhadap persamaan (5) maka diperoleh model sebagai berikut:

$\mathrm{P}_{0} / \mathrm{E}_{0}=(1-\mathrm{b})\left\{1+[\mathrm{TAT} \times \mathrm{NPM}(1+\mathrm{D} / \mathrm{E})\} /\left(\mathrm{K}_{\mathrm{e}}-\mathrm{bR}\right)\right.$

Persamaan (7) menjelaskan bahwa price earnings ratio (PER) secara fundamental adalah fungsi dari retention ratio (b), total assets turnover (TAT), net profit margin (NPM), debt to equity ratio $(\mathrm{D} / \mathrm{E})$, dividend payout ratio $(\mathrm{DPR})$, growth $(\mathrm{g})$, return on equity $(\mathrm{ROE})$, dan tingkat kapitalisasi $\left(\mathrm{K}_{\mathrm{e}}\right)$.

\section{METODE PENELITIAN}

Dalam penelitian ini, jenis variabel yang dipergunakan adalah variabel berdasarkan fungsinya yang terdiri dari: variabel dependen dan variabel independen. Variabel dependen adalah price earnings ratio (PER), yaitu rasio harga saham dengan pendapatan per lembar saham yang satuan ukurannya adalah kali.

Variabel independen adalah total assets turnover (TAT), net profit margin (NPM), debt to equity ratio (DER), dividend payout ratio (DPR), retention ratio (RR), growth (GRT), return on equity (ROE), dan tingkat kapitalisasi atau imbal hasil yang diharapkan (IHD).

Total assets turnover (TAT) adalah perputaran harta yang ditentukan melalui perbandingan antara penjualan dengan jumlah harta yang satuan ukurannya adalah kali. Net profit margin (NPM) adalah marjin laba bersih yang diukur dengan mempergunakan rasio antara laba bersih dengan penjualan yang satuan ukurannya adalah kali, debt to equity ratio (DER) merupakan rasio antara utang dengan ekuitas yang satuan ukurannya adalah kali, dividend payout ratio (DPR) merupakan rasio pembayaran dividen dengan laba bersih yang satuan ukurannya adalah persentase, retention ratio (RR) merupakan rasio laba ditahan dengan laba bersih yang satuan ukurannya adalah persentase, growth (GRT) menggambarkan pertumbuhan perusahaan dari periode $t+1$ ke periode $t$ yang satuan ukurannya adalah persentase, return on equity (ROE) merupakan rasio antara laba bersih dengan ekuitas yang satuan ukurannya adalah persentase, dan tingkat kapitalisasi atau imbal hasil yang disyaratkan (IHD) merupakan rasio antara pendapatan per lembar saham dengan harga saham.yang satuan ukurannya adalah kali.

Populasi dalam penelitian ini adalah semua perusahaan-perusahaan manufaktur yang terdaftar di Bursa Efek Indonesia pada akhir tahun 2013. Jumlah perusahaan-perusahaan manufaktur yang terdaftar di bursa efek Indonesia pada akhir tahun 2013 sebanyak 256 perusahaan. Dengan mengeliminasi perusahaan-perusahaan yang baru mengemisikan sahamnya pada periode penelitian, perusahaan-perusahaan yang sahamnya jarang diperdagangkan, dan perusahaanperusahaan yang tidak memiliki data harga saham lengkap, maka sample size sebanyak 98 perusahaan. Dengan demikian, teknik pengambilan sampel dalam penelitian ini adalah mempergunakan teknik purposive sampling (Indriantoro dan Supomo: 1999).

Data yang dipergunakan dalam penelitian ini adalah data sekunder, yaitu: data harga saham penutupan, data pendapatan per lembar saham, data penjualan, data jumlah harta, data jumlah 
utang, data jumlah ekuitas, data laba bersih, data jumlah dividen yang dibayarkan masing-masing perusahaan yang menjadi sampel penelitian. Semua data tersebut didapatkan dari Indonesian Capital Market Directory Tahun 2013. Dengan demikian teknik pengambilan data adalah teknik dokumentasi.

Berdasarkan model teoritis yang telah dikemukakan, maka dalam menjelaskan determinan price earnings ratio (PER) dipergunakan 8 (delapan) model regressi. Model-model tersebut adalah sebagai berikut:

$$
\begin{aligned}
& P E R=\alpha_{0}+\beta_{1} R R+\beta_{2} R O E+\beta_{3} \text { IHD }+\varepsilon \\
& P E R=\alpha_{0}+\beta_{1} R R+\beta_{2} \text { GRT }+\beta_{3} \text { IHD }+\varepsilon
\end{aligned}
$$

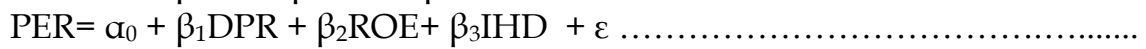

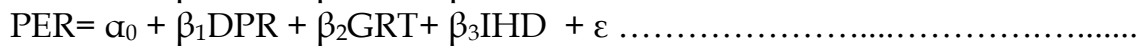

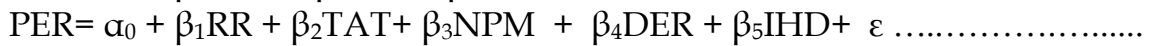

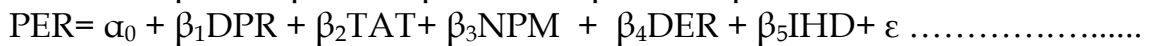

$$
\begin{aligned}
& \mathrm{PER}=\alpha_{0}+\beta_{1} \mathrm{RR}+\beta_{2} \mathrm{TAT}+\beta_{3} \mathrm{NPM}+\beta_{4} \mathrm{DER}+\beta_{5} \mathrm{IHD}+\beta_{6} \mathrm{GRT}+\varepsilon \ldots \ldots \ldots . . \\
& \mathrm{PER}=\mathrm{a}_{0}+\beta_{1} \mathrm{DPR}+\beta_{2} \mathrm{TAT}+\beta_{3} \mathrm{NPM}+\beta_{4} \mathrm{DER}+\beta_{5} \mathrm{IHD}+\beta_{6} \mathrm{GRT}+\varepsilon \ldots \ldots \ldots .
\end{aligned}
$$

dimana PER merupakan price earnings ratio, $\mathrm{RR}$ merupakan retention ratio, $\mathrm{ROE}$ merupakan return on equity, IHD merupakan imbal hasil yang disyaratkan atau tingkat kapitalisasi, GRT merupakan growth, DPR merupakan dividend payout ratio, TAT merupakan total assets turnover, NPM merupakan net profit margin, DER merupakan debt to equity ratio, a merupakan konstanta, $\beta_{1 . .6}$ merupakan koefisien pengaruh variabel bebas terhadap price earnings ratio.

Persamaan dalam penelitian ini menggunakan logaritma natural dengan alasan untuk menghomogenitaskan data yang heterogen dan hasil estimasi koefisien secara langsung menjadi besaran elastisitas masing-masing variabel fundamental terhadap price earnings ratio.

Untuk menjelaskan pengaruh masing-masing variabel bebas terhadap price earnings ratio diuji dengan mempergunakan uji $t$ dengan a sebesar 10 persen. Selanjutnya, untuk menjelaskan pengaruh secara serentak variabel bebas terhadap price earnings ratio dipergunakan uji $\mathrm{F}$ dengan a sebesar 10 persen serta untuk mengolah data dipergunakan program SPSS Version 18.

\section{HASIL PENELITIAN DAN PEMBAHASAN Deskripsi Variabel Penelitian}

Berdasarkan pengamatan terhadap data 98 perusahaan-perusahaan manufaktur yang terdaftar di Bursa Efek Indonesia tahun 2013, deskripsi variabel price earnings ratio (PER), total assets turnover (TAT), net profit margin (NPM), debt to equity ratio (DER), dividend payout ratio (DPR), return on equity (ROE), imbal hasil yang disyaratkan (IHD), growth (GRT), dan retention ratio (RR)

\begin{tabular}{|c|c|c|c|c|c|}
\hline Variabel & $\mathrm{N}$ & Minimum & Maximum & Mean & Std. Deviation \\
\hline PER & 98 & .0010 & 1229.0000 & 15.1037 & 123.9562 \\
\hline TAT & 98 & .2400 & 3.6800 & 1.2308 & .59440 \\
\hline NPM & 98 & .0001 & 10.0200 & .3043 & 1.15748 \\
\hline DER & 98 & .0010 & 4.6700 & 1.0812 & .9277 \\
\hline DPR & 98 & .0001 & 264.2300 & 17.0925 & 37.7795 \\
\hline ROE & 98 & -43.2900 & 93.9900 & 15.0830 & 17.8370 \\
\hline $\mathrm{IHD}$ & 98 & .0002 & 10000.0000 & 102.1462 & $1.0101418 \mathrm{E} 3$ \\
\hline GRT & 98 & .0000 & 8.6928E187 & $9.247660 \mathrm{E} 18$ & 1.5535387E119 \\
\hline RR & 98 & -164.2300 & 99.9999 & 82.9074 & 37.7795 \\
\hline
\end{tabular}
ditunjukkan pada Tabel 1 berikut ini.

Tabel 1. Statistik Deskripsi Variabel-Variabel Penelitian

Sumber: Hasil Penelitian dan Sudah Diolah.

Berdasarkan Tabel 1 tersebut dapat dikemukakan bahwa rata-rata price earnings ratio (PER) adalah 15,10 kali dengan standar deviasi sebesar 123,956. Kondisi ini menggambarkan bahwa price earnings ratio (PER) yang diamati cukup fluktuatif. Rata-rata total assets turnover (TAT) adalah 1,23 kali dengan standar deviasi sebesar 0,594. Kondisi ini menggambarkan 
bahwa total assets turnover (TAT) yang diamati relatif berfluktuasi. Rata-rata net profit margin (NPM) adalah 0,30 kali dengan standar deviasi sebesar 1,157. Kondisi ini menggambarkan bahwa net profit margin (NPM) yang diamati cukup fluktuatif. Rata-rata debt to equity ratio (DER) adalah 1,08 kali dengan standar deviasi sebesar 0,928. Kondisi ini menggambarkan bahwa debt to equity ratio (DER) yang diamati cukup fluktuatif. Rata-rata dividend payout ratio (DPR) adalah 17,09 persen dengan standar deviasi sebesar 37,780. Kondisi ini menggambarkan bahwa dividend payout ratio (DPR) yang diamati cukup fluktuatif. Rata-rata return on equity (ROE) adalah 15,08 persen dengan standar deviasi sebesar 17,837. Kondisi ini menggambarkan bahwa return on equity (ROE) yang diamati cukup fluktuatif. Rata-rata imbal hasil yang disyaratkan (IHD) adalah 102,15 kali dengan standar deviasi sebesar 1.010,142. Kondisi ini menggambarkan bahwa imbal hasil yang disyaratkan (IHD) cukup fluktuatif. Rata-rata growth (GRT) adalah 2.08E13 kali dengan standar deviasi sebesar 1.017E14. Kondisi ini menggambarkan bahwa growth (GRT) yang diamati cukup fluktuatif. Rata-rata retention ratio (RR) adalah 82,19 persen dengan standar deviasi sebesar 37,780. Kondisi ini menggambarkan bahwa retention ratio (RR) yang diamati cukup fluktuatif.

\section{Hasil Estimasi Model Penelitian}

Mengacu pada model analisis, determinan price earnings ratio (PER) dapat dijelaskan melalui 8 (delapan) model. Pertama, rekapitulasi hasil estimasi pengaruh retention ratio (RR), return on equity (ROE), dan imbal hasil yang disyaratkan (IHD) terhadap price earnings ratio (PER) dapat dilihat pada Tabel 2 berikut.

Tabel 2. Rekapitulasi Hasil Penelitian Pengaruh Retention Ratio, Return on Equity dan Imbal Hasil Yang Disyaratkan Terhadap Price Earnings Ratio

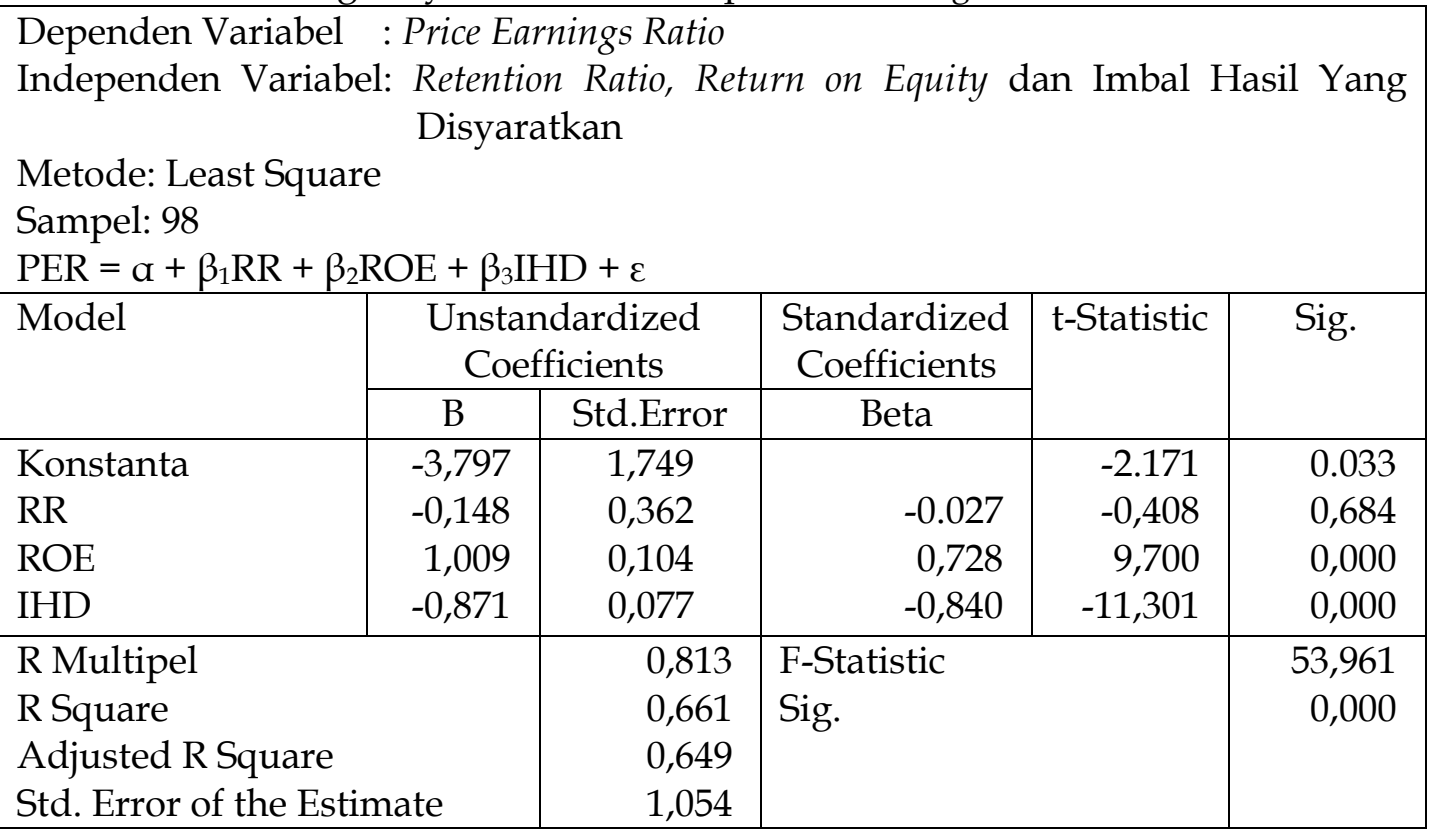

Sumber: Hasil Olahan Data Penelitian dengan Mempergunakan Program SPSS Version 18.

Berdasarkan Tabel 2 tersebut di atas, dapat dikemukakan bahwa nilai koefisien determinan sebesar 66,1 persen dengan nilai F-statistik adalah 53,961, dan probabilitas sebesar 0,000 . Selanjutnya, nilai koefisien regressi standardisasi variabel retention ratio (RR) sebesar 0,148 dengan nilai t-satistik adalah -0,027 dan probabilitas sebesar 0,684. Oleh karenanya dapat dikemukakan bahwa retention ratio (RR) tidak berpengaruh terhadap price earnings ratio (PER). Nilai koefisien regressi standardisasi variabel return on equity (ROE) sebesar 0,728 dengan nilai 
t-satistik adalah 9,700 dan probabilitas sebesar 0,000. Dengan demikian dapat dikemukakan bahwa return on equity (ROE) berpengaruh positip dan signifikan terhadap price earnings ratio (PER). Nilai koefisien regressi standardisasi variabel imbal hasil yang disyaratkan (IHD) sebesar $-0,840$ dengan nilai t-satistik adalah $-11,301$ dan probabilitas sebesar 0,000. Oleh karena itu, dapat dikemukakan bahwa imbal hasil yang disyaratkan (IHD) berpengaruh negatip dan signifikan terhadap price earnings ratio (PER).

Kedua, rekapitulasi hasil estimasi pengaruh retention ratio (RR), growth (GRT), dan imbal hasil yang disyaratkan (IHD) terhadap price earnings ratio (PER) dapat dilihat pada Tabel 3 berikut.

Tabel 3. Rekapitulasi Hasil Penelitian Pengaruh Retention Ratio, Growth dan Imbal Hasil Yang Disyaratkan Terhadap Price Earnings Ratio

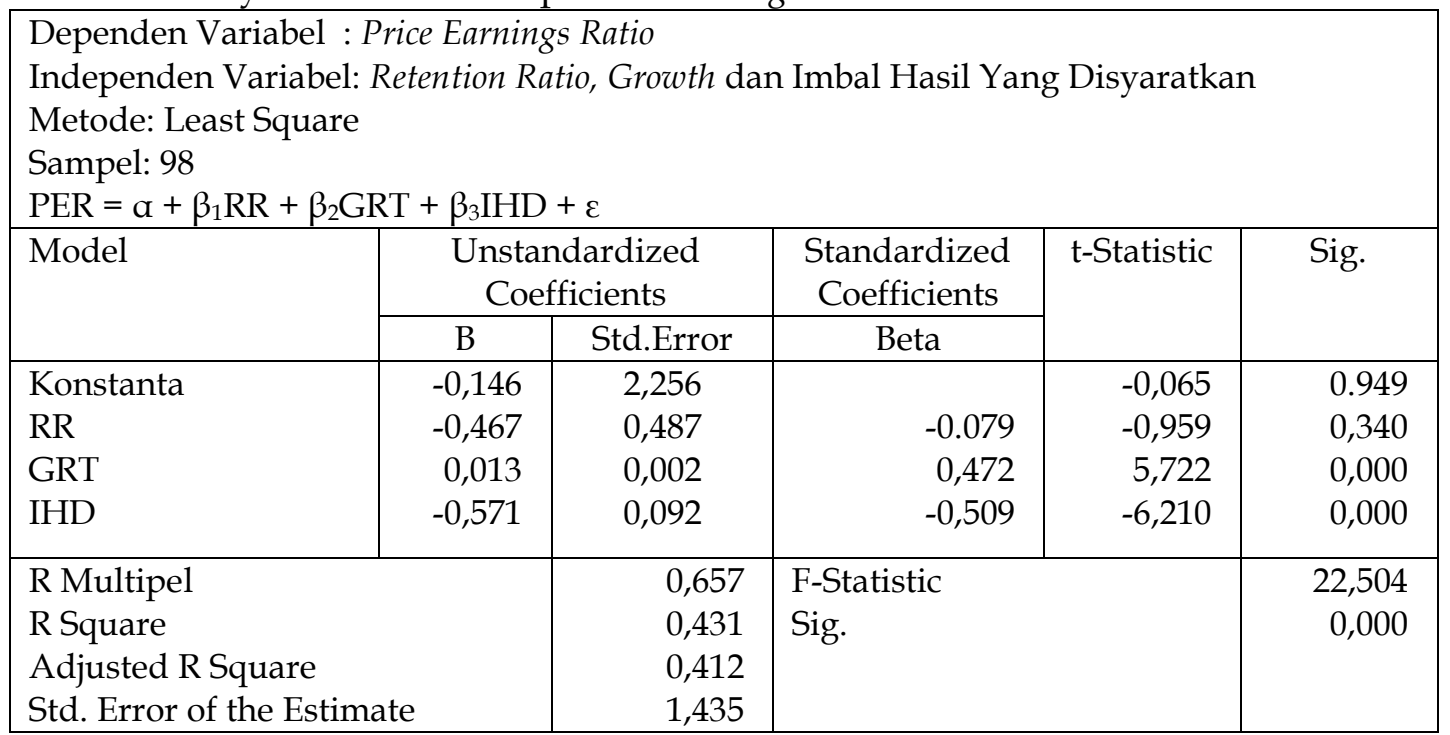

Sumber: Hasil Olahan Data Penelitian dengan Mempergunakan Program SPSS Version 18.

Berdasarkan Tabel 3 tersebut di atas, dapat dikemukakan bahwa nilai koefisien determinan sebesar 43,1 persen dengan nilai F-statistik adalah 22,504, dan probabilitas sebesar 0,000 . Selanjutnya, nilai koefisien regressi standardisasi variabel retention ratio (RR) sebesar 0,079 dengan nilai t-satistik adalah -0,959 dan probabilitas sebesar 0,340. Oleh karenanya dapat dikemukakan bahwa retention ratio (RR) tidak berpengaruh terhadap price earnings ratio (PER). Nilai koefisien regressi standardisasi variabel growth (GRT) sebesar 0,472 dengan nilai t-satistik adalah 5,722 dan probabilitas sebesar 0,000. Dengan demikian dapat dikemukakan bahwa growth (GRT) berpengaruh positip dan signifikan terhadap price earnings ratio (PER). Nilai koefisien regressi standardisasi variabel imbal hasil yang disyaratkan (IHD) sebesar -0,509 dengan nilai t-satistik adalah -6,201 dan probabilitas sebesar 0,000. Oleh karena itu, dapat dikemukakan bahwa imbal hasil yang disyaratkan (IHD) berpengaruh negatip dan signifikan terhadap price earnings ratio (PER).

Ketiga, rekapitulasi hasil estimasi pengaruh dividend payout ratio (DPR), return on equity (ROE), dan imbal hasil yang disyaratkan (IHD) terhadap price earnings ratio (PER) dapat dilihat pada Tabel 4 berikut.

Tabel 4. Rekapitulasi Hasil Penelitian Pengaruh Dividend Payout Ratio, Return on Equity dan Imbal Hasil Yang Disyaratkan Terhadap Price Earnings Ratio

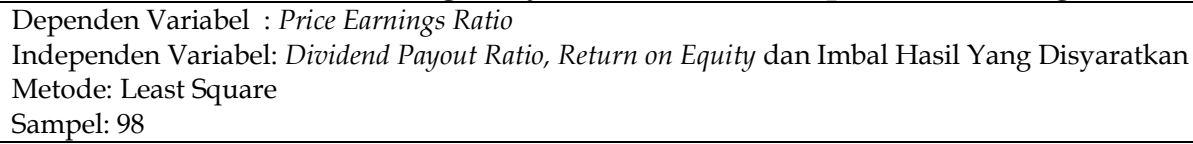




\begin{tabular}{|c|c|c|c|c|c|}
\hline \multicolumn{6}{|c|}{ PER $=\alpha+\beta_{1}$ DPR $+\beta_{2}$ ROE $+\beta_{3}$ IHD $+\varepsilon$} \\
\hline \multirow[t]{2}{*}{ Model } & \multicolumn{2}{|c|}{ Unstandardized Coefficients } & \multirow{2}{*}{$\begin{array}{c}\begin{array}{c}\text { Standardized } \\
\text { Coefficients }\end{array} \\
\text { Beta } \\
\end{array}$} & \multirow[t]{2}{*}{ t-Statistic } & \multirow[t]{2}{*}{ Sig. } \\
\hline & B & Std.Error & & & \\
\hline Konstanta & $-4,382$ & 0,420 & & $-10,433$ & 0.000 \\
\hline DPR & 0,014 & 0,019 & 0.046 & 0,704 & 0,483 \\
\hline ROE & 1,001 & 0,103 & 0,712 & 9,709 & 0,000 \\
\hline IHD & $-0,874$ & 0,073 & $-0,824$ & $-11,989$ & 0,000 \\
\hline \multirow{4}{*}{\multicolumn{2}{|c|}{$\begin{array}{l}\text { R Multipel } \\
\text { R Square } \\
\text { Adjusted R Square } \\
\text { Std. Error of the Estimate }\end{array}$}} & 0,829 & \multirow{4}{*}{\multicolumn{2}{|c|}{$\begin{array}{l}\text { F-Statistic } \\
\text { Sig. }\end{array}$}} & 64,234 \\
\hline & & 0,686 & & & 0,000 \\
\hline & & 0,676 & & & \\
\hline & & 1,023 & & & \\
\hline
\end{tabular}

Sumber: Hasil Olahan Data Penelitian dengan Mempergunakan Program SPSS Version 18.

Berdasarkan Tabel 4 tersebut di atas, dapat dikemukakan bahwa nilai koefisien determinan sebesar 68,6 persen dengan nilai F-statistik adalah 64,234, dan probabilitas sebesar 0,000. Selanjutnya, nilai koefisien regressi standardisasi variabel dividend payout ratio (DPR) sebesar 0,046 dengan nilai t-satistik adalah 0,704 dan probabilitas sebesar 0,483 . Oleh karenanya dapat dikemukakan bahwa dividend payout ratio (DPR) tidak berpengaruh terhadap price earnings ratio (PER). Nilai koefisien regressi standardisasi variabel return on equity (ROE) sebesar 0,712 dengan nilai t-satistik adalah 9,709 dan probabilitas sebesar 0,000. Dengan demikian dapat dikemukakan bahwa return on equity (GRT) berpengaruh positip dan signifikan terhadap price earnings ratio (PER). Nilai koefisien regressi standardisasi variabel imbal hasil yang disyaratkan (IHD) sebesar -0,824 dengan nilai t-satistik adalah -11,989 dan probabilitas sebesar 0,000. Oleh karena itu, dapat dikemukakan bahwa imbal hasil yang disyaratkan (IHD) berpengaruh negatip dan signifikan terhadap price earnings ratio (PER).

Keempat, rekapitulasi hasil estimasi pengaruh dividend payout ratio (DPR), growth (GRT), dan imbal hasil yang disyaratkan (IHD) terhadap price earnings ratio (PER) dapat dilihat pada Tabel 5 berikut.

Tabel 5. Rekapitulasi Hasil Penelitian Pengaruh Dividend Payout Ratio, Growth dan Imbal Hasil Yang Disyaratkan Terhadap Price Earnings Ratio

\begin{tabular}{|c|c|c|c|c|c|}
\hline $\begin{array}{l}\text { Dependen Variabel : Price } \\
\text { Independen Variabel: Divt } \\
\text { Metode: Least Square } \\
\text { Sampel: } 98 \\
\text { PER }=\alpha+\beta_{1} \mathrm{DPR}+\beta_{2} \mathrm{GRT}\end{array}$ & $\begin{array}{l}\text { rnings Ratio } \\
\text { d Payout Ra } \\
3_{3} \mathrm{IHD}+\varepsilon\end{array}$ & rowth dan Imb & 1 Hasil Yang Disyar & & \\
\hline Model & Unstandar & Coefficients & Standardized & t-Statistic & Sig. \\
\hline & B & Std.Error & Beta & & \\
\hline Konstanta & $-1,865$ & 0,358 & & $-5,206$ & 0.000 \\
\hline DPR & 0,048 & 0,027 & 0.150 & 1.804 & 0,075 \\
\hline GRT & 0,011 & 0,002 & 0,445 & 5.285 & 0,000 \\
\hline IHD & $-0,560$ & 0,090 & $-0,495$ & $-6,200$ & 0,000 \\
\hline R Multipel & & 0,665 & F-Statistic & & 23,807 \\
\hline R Square & & 0,442 & Sig. & & 0,000 \\
\hline Adjusted R Square & & 0,424 & & & \\
\hline Std. Error of the Estimate & & 1,427 & & & \\
\hline
\end{tabular}

Sumber: Hasil Olahan Data Penelitian dengan Mempergunakan Program SPSS Version 18.

Berdasarkan Tabel 5 tersebut di atas, dapat dikemukakan bahwa nilai koefisien determinan sebesar 44,2 persen dengan nilai F-statistik adalah 23,807, dan probabilitas sebesar 0,000 . Selanjutnya, nilai koefisien regressi standardisasi variabel dividend payout ratio (DPR) sebesar 0,150 dengan nilai t-satistik adalah 1,804 dan probabilitas sebesar 0,075. Oleh karenanya dapat dikemukakan bahwa dividend payout ratio (DPR) berpengaruh positip dan signifikan 
terhadap price earnings ratio (PER). Nilai koefisien regressi standardisasi variabel growth (GRT) sebesar 0,445 dengan nilai t-satistik adalah 5,282 dan probabilitas sebesar 0,000. Dengan demikian dapat dikemukakan bahwa growth (GRT) berpengaruh positip dan signifikan terhadap price earnings ratio (PER). Nilai koefisien regressi standardisasi variabel imbal hasil yang disyaratkan (IHD) sebesar -0,495 dengan nilai t-satistik adalah -6,200 dan probabilitas sebesar 0,000. Oleh karena itu, dapat dikemukakan bahwa imbal hasil yang disyaratkan (IHD) berpengaruh negatip dan signifikan terhadap price earnings ratio (PER).

Kelima, rekapitulasi hasil estimasi pengaruh retention ratio (RR), total assets turnover (TAT), net profit margin (NPM), debt to equity ratio (DER) dan imbal hasil yang disyaratkan (IHD) terhadap price earnings ratio (PER) dapat dilihat pada Tabel 6.

Tabel 6. Rekapitulasi Hasil Penelitian Pengaruh Retention Ratio, Total Assets Turnover, Nep Profit Margin, Debt to Equity Ratio dan Imbal Hasil Yang Disyaratkan Terhadap Price Earnings Ratio

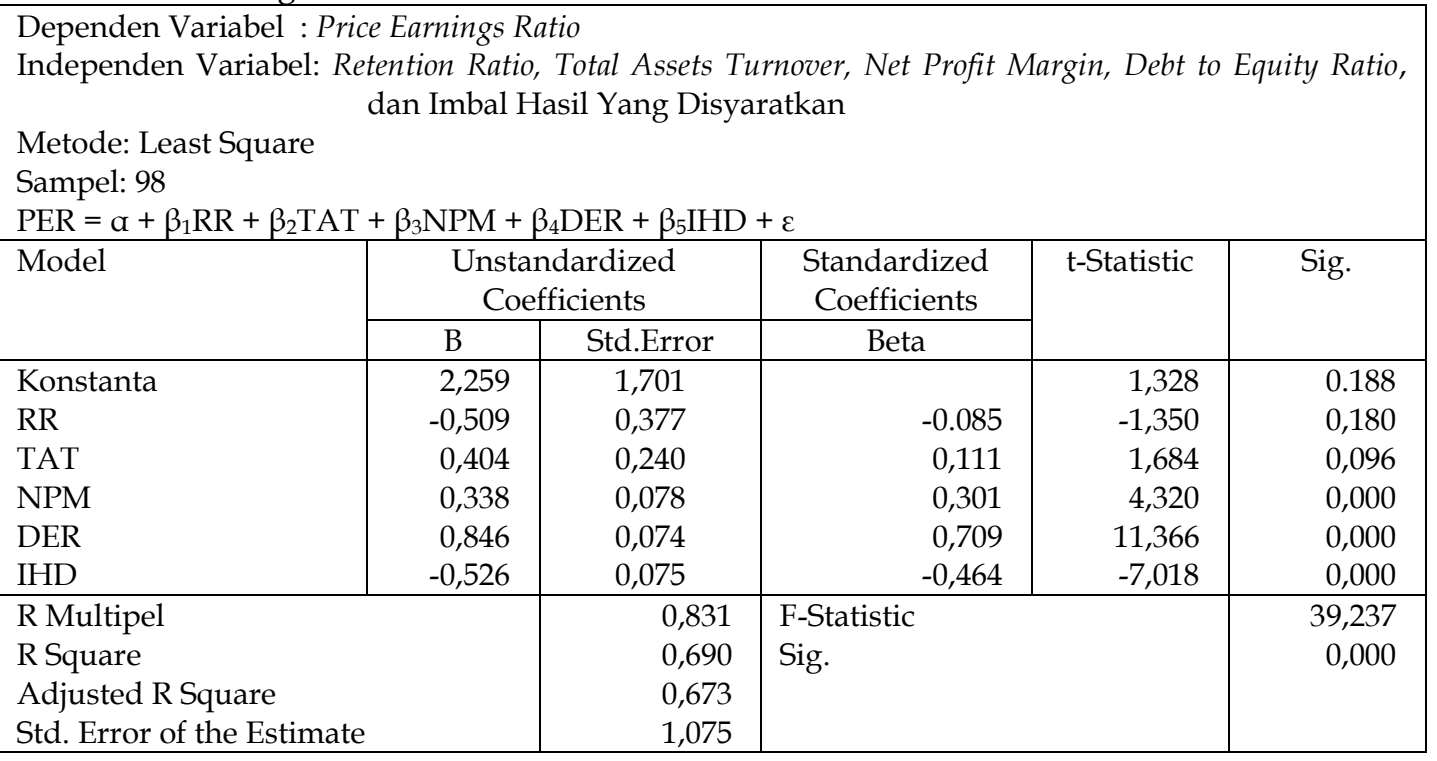

Sumber: Hasil Olahan Data Penelitian dengan Mempergunakan Program SPSS Version 18.

Berdasarkan Tabel 6 tersebut di atas, dapat dikemukakan bahwa nilai koefisien determinan sebesar 69 persen dengan nilai F-statistik adalah 38,237, dan probabilitas sebesar 0,000 . Selanjutnya, nilai koefisien regressi standardisasi variabel retention ratio (RR) sebesar 0,085 dengan nilai t-satistik adalah -1,350 dan probabilitas sebesar 0,180. Oleh karenanya dapat dikemukakan bahwa retention ratio (RR) tidak berpengaruh terhadap price earnings ratio (PER). Nilai koefisien regressi standardisasi variabel total assets turnover (TAT) sebesar 0,111 dengan nilai t-satistik adalah 1,684 dan probabilitas sebesar 0,096. Dengan demikian dapat dikemukakan bahwa total assets turnover (TAT) berpengaruh positip dan signifikan terhadap price earnings ratio (PER). Nilai koefisien regressi standardisasi variabel net profit margin (NPM) sebesar 0,301 dengan nilai t-statistik adalah 4,320 dan probabilitas sebesar 0,000. Dengan demikian dapat dikemukakan bahwa net profit margin (NPM) berpengaruh positip dan signifikan terhadap price earnings ratio (PER).

Nilai koefisien standardisasi variabel debt to equity ratio (DER) sebesar 0,709 dengan nilai t-statistik sebesar 11,366 dan probabilitas adalah 0,000. Oleh karenanya dapat dikemukakan bahwa debt to equity ratio berpengaruh positip dan signifikan terhadap price earnings ratio (PER). Nilai koefisien standardisasi variabel imbal hasil yang disyaratkan (IHD) sebesar -0,464 dengan nilai t-satistik adalah -7,018 dan probabilitas sebesar 0,000. Oleh karena itu, dapat dikemukakan 
bahwa imbal hasil yang disyaratkan (IHD) berpengaruh negatip dan signifikan terhadap price earnings ratio (PER).

Keenam, rekapitulasi hasil estimasi pengaruh retention ratio (RR), total assets turnover (TAT), net profit margin (NPM), debt to equity ratio (DER) dan imbal hasil yang disyaratkan (IHD) terhadap price earnings ratio (PER) dapat dilihat pada Tabel 7 berikut.

Tabel 7. Rekapitulasi Hasil Penelitian Pengaruh Dividend Payout Ratio, Total Assets Turnover, Net

Profit Margin, Debt to Equity Ratio dan Imbal Hasil Yang Disyaratkan Terhadap Price Earnings Ratio

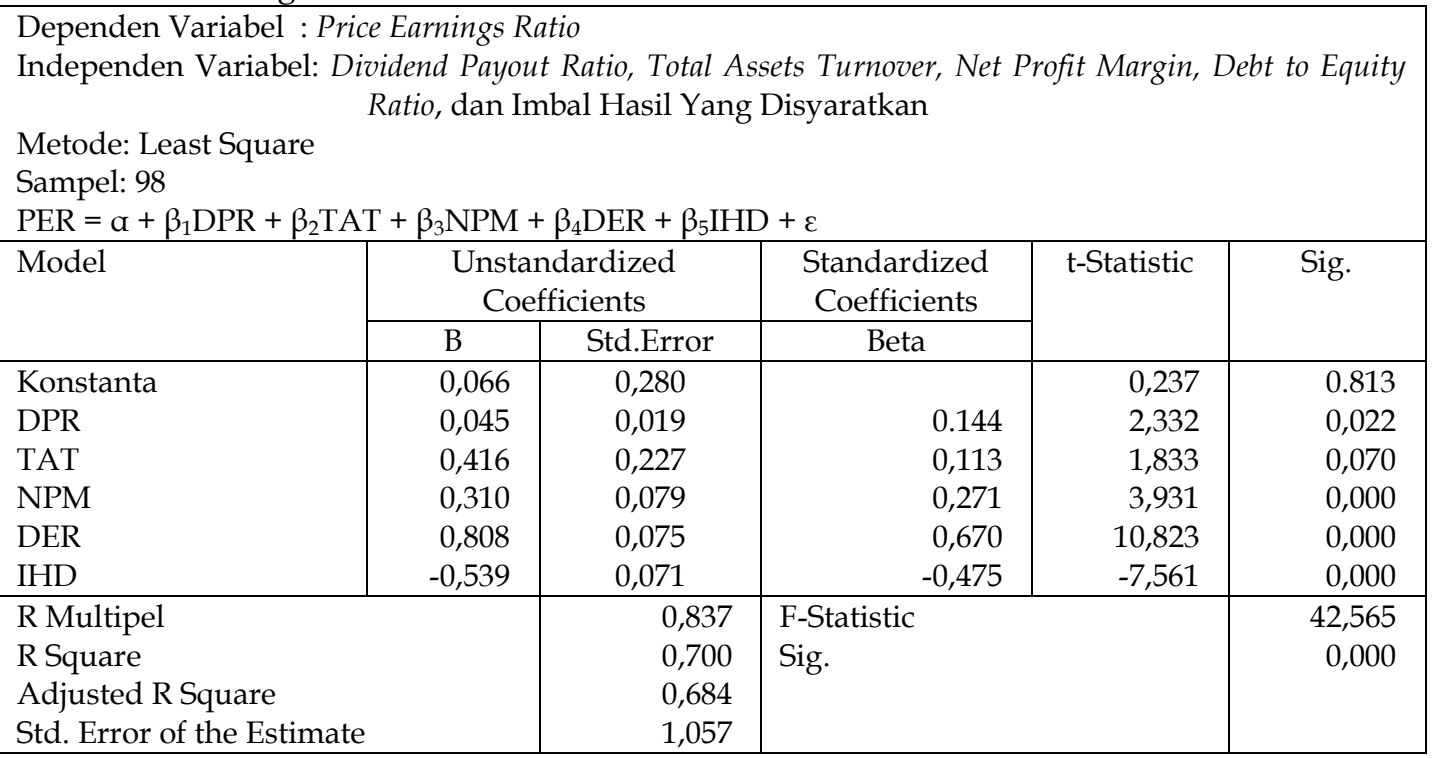

Sumber: Hasil Olahan Data Penelitian dengan Mempergunakan Program SPSS Version 18.

Berdasarkan Tabel 7 tersebut di atas, dapat dikemukakan bahwa nilai koefisien determinan sebesar 70 persen dengan nilai F-statistik adalah 42,565, dan probabilitas sebesar 0,000. Selanjutnya, nilai koefisien regressi standardisasi variabel dividend payout ratio (DPR) sebesar 0,144 dengan nilai t-satistik adalah 2,332 dan probabilitas sebesar 0,022 . Oleh karenanya dapat dikemukakan bahwa dividend payout ratio (DPR) berpengaruh positip dan signifikan terhadap price earnings ratio (PER). Nilai koefisien regressi standardisasi variabel total assets turnover (TAT) sebesar 0,113 dengan nilai t-satistik adalah 1,833 dan probabilitas sebesar 0,070. Dengan demikian dapat dikemukakan bahwa total assets turnover (TAT) berpengaruh positip dan signifikan terhadap price earnings ratio (PER). Nilai koefisien regressi standardisasi variabel net profit margin (NPM) sebesar 0,271 dengan nilai t-statistik adalah 3,931 dan probabilitas sebesar 0,000. Dengan demikian dapat dikemukakan bahwa net profit margin (NPM) berpengaruh positip dan signifikan terhadap price earnings ratio (PER). Nilai koefisien standardisasi variabel debt to equity ratio (DER) sebesar 0,670 dengan nilai t-statistik sebesar 10,823 dan probabilitas adalah 0,000. Oleh karenanya dapat dikemukakan bahwa debt to equity ratio berpengaruh positip dan signifikan terhadap price earnings ratio (PER). Nilai koefisien standardisasi variabel imbal hasil yang disyaratkan (IHD) sebesar -0,475 dengan nilai t-satistik adalah -7,561 dan probabilitas sebesar 0,000. Oleh karena itu, dapat dikemukakan bahwa imbal hasil yang disyaratkan (IHD) berpengaruh negatip dan signifikan terhadap price earnings ratio (PER).

Ketujuh, rekapitulasi hasil estimasi pengaruh retention ratio (RR), total assets turnover (TAT), net profit margin (NPM), debt to equity ratio (DER), imbal hasil yang disyaratkan (IHD), dan growth (GRT) terhadap price earnings ratio (PER) dapat dilihat pada Tabel 8 berikut. 
Tabel 8. Rekapitulasi Hasil Penelitian Pengaruh Retention Ratio, Total assets Turnover, Net Profit Margin, Debt to Equity Ratio, Imbal Hasil Yang Disyaratkan dan Growth Terhadap Price Earnings Ratio

\begin{tabular}{|c|c|c|c|c|}
\hline \multicolumn{5}{|c|}{$\begin{array}{l}\text { Dependen Variabel : Price Earnings Ratio } \\
\text { Independen Variabel: Retention Ratio, Total Assets Turnover, Ne } \\
\qquad \text { Equity Ratio, Imbal Hasil Yang Disyaratkan } \\
\text { Metode: Least Square } \\
\text { Sampel: } 98 \\
\text { PER }=\alpha+\beta_{1} \mathrm{RR}+\beta_{2} \mathrm{TAT}+\beta_{3} \mathrm{NPM}+\beta_{4} \mathrm{DER}+\beta_{5} \mathrm{IHD}+\beta_{6} \mathrm{GRT}+\varepsilon\end{array}$} \\
\hline \multirow[t]{2}{*}{ Model } & $\begin{array}{l}\text { Unstandardized } \\
\text { Coefficients }\end{array}$ & $\begin{array}{c}\text { Standardized } \\
\text { Coefficients }\end{array}$ & \multirow[t]{2}{*}{ t-Statistic } & \multirow[t]{2}{*}{ Sig. } \\
\hline & Std.Error & Beta & & \\
\hline Konstanta & 1,548 & & 0,499 & 0.619 \\
\hline$-0,374$ & 0,337 & -0.063 & $-1,108$ & 0,271 \\
\hline 0,378 & 0,214 & 0,103 & 1,763 & 0,081 \\
\hline NPM & 0,074 & 0,191 & 2,901 & 0,005 \\
\hline 0,740 & 0,070 & 0,621 & 10,603 & 0,000 \\
\hline$-0,546$ & 0,067 & $-0,482$ & $-8,153$ & 0,000 \\
\hline GRT & 0,001 & 0,288 & 4,854 & 0,000 \\
\hline \multirow{4}{*}{$\begin{array}{l}\text { R Multipel } \\
\text { R Square } \\
\text { Adjusted R Square } \\
\text { Std. Error of the Estimate }\end{array}$} & 0,870 & \multirow{4}{*}{\multicolumn{2}{|c|}{$\begin{array}{l}\text { F-Statistic } \\
\text { Sig. }\end{array}$}} & 45,006 \\
\hline & 0,756 & & & 0,000 \\
\hline & 0,740 & & & \\
\hline & 0,959 & & & \\
\hline
\end{tabular}

Sumber: Hasil Olahan Data Penelitian dengan Mempergunakan Program SPSS Version 18.

Berdasarkan Tabel 8 tersebut di atas, dapat dikemukakan bahwa nilai koefisien determinan sebesar 75,6 persen dengan nilai F-statistik adalah 45,006, dan probabilitas sebesar 0,000. Selanjutnya, nilai koefisien regressi standardisasi variabel retention ratio (RR) sebesar 0,063 dengan nilai t-satistik adalah -1,108 dan probabilitas sebesar 0,271. Oleh karenanya dapat dikemukakan bahwa retention ratio (RR) tidak berpengaruh terhadap price earnings ratio (PER). Nilai koefisien regressi standardisasi variabel total assets turnover (TAT) sebesar 0,103 dengan nilai t-satistik adalah 1,763 dan probabilitas sebesar 0,081. Dengan demikian dapat dikemukakan bahwa total assets turnover (TAT) berpengaruh positip dan signifikan terhadap price earnings ratio (PER). Nilai koefisien regressi standardisasi variabel net profit margin (NPM) sebesar 0,191 dengan nilai t-statistik adalah 2,901 dan probabilitas sebesar 0,005. Dengan demikian dapat dikemukakan bahwa net profit margin (NPM) berpengaruh positip dan signifikan terhadap price earnings ratio (PER). Nilai koefisien standardisasi variabel debt to equity ratio (DER) sebesar 0,621 dengan nilai t-statistik sebesar 10,603 dan probabilitas adalah 0,000. Oleh karenanya dapat dikemukakan bahwa debt to equity ratio berpengaruh positip dan signifikan terhadap price earnings ratio (PER). Nilai koefisien standardisasi variabel imbal hasil yang disyaratkan (IHD) sebesar -0,482 dengan nilai t-satistik adalah -8,153 dan probabilitas sebesar 0,000. Oleh karena itu, dapat dikemukakan bahwa imbal hasil yang disyaratkan (IHD) berpengaruh negatip dan signifikan terhadap price earnings ratio (PER). Nilai koefisien standardisasi variabel growth (GRT) adalah 0,288 dengan nilai t-statistik sebesar 4,854 dan probabilitas sebesar 0,000. Oleh karena itu dapat dikemukakan bahwa growth berpengaruh positip dan signifikan terhadap price earnings ratio (PER).

Kedelapan, rekapitulasi hasil estimasi pengaruh dividend payout ratio (DPR), total assets turnover (TAT), net profit margin (NPM), debt to equity ratio (DER), imbal hasil yang disyaratkan (IHD), dan growth (GRT) terhadap price earnings ratio (PER) dapat dilihat pada Tabel 9 berikut. 
Tabel 9. Rekapitulasi Hasil Penelitian Pengaruh Dividend Payout Ratio, Total assets Turnover, Net Profit Margin, Debt to Equity Ratio, Imbal Hasil Yang Disyaratkan dan Growth Terhadap Price Earnings Ratio

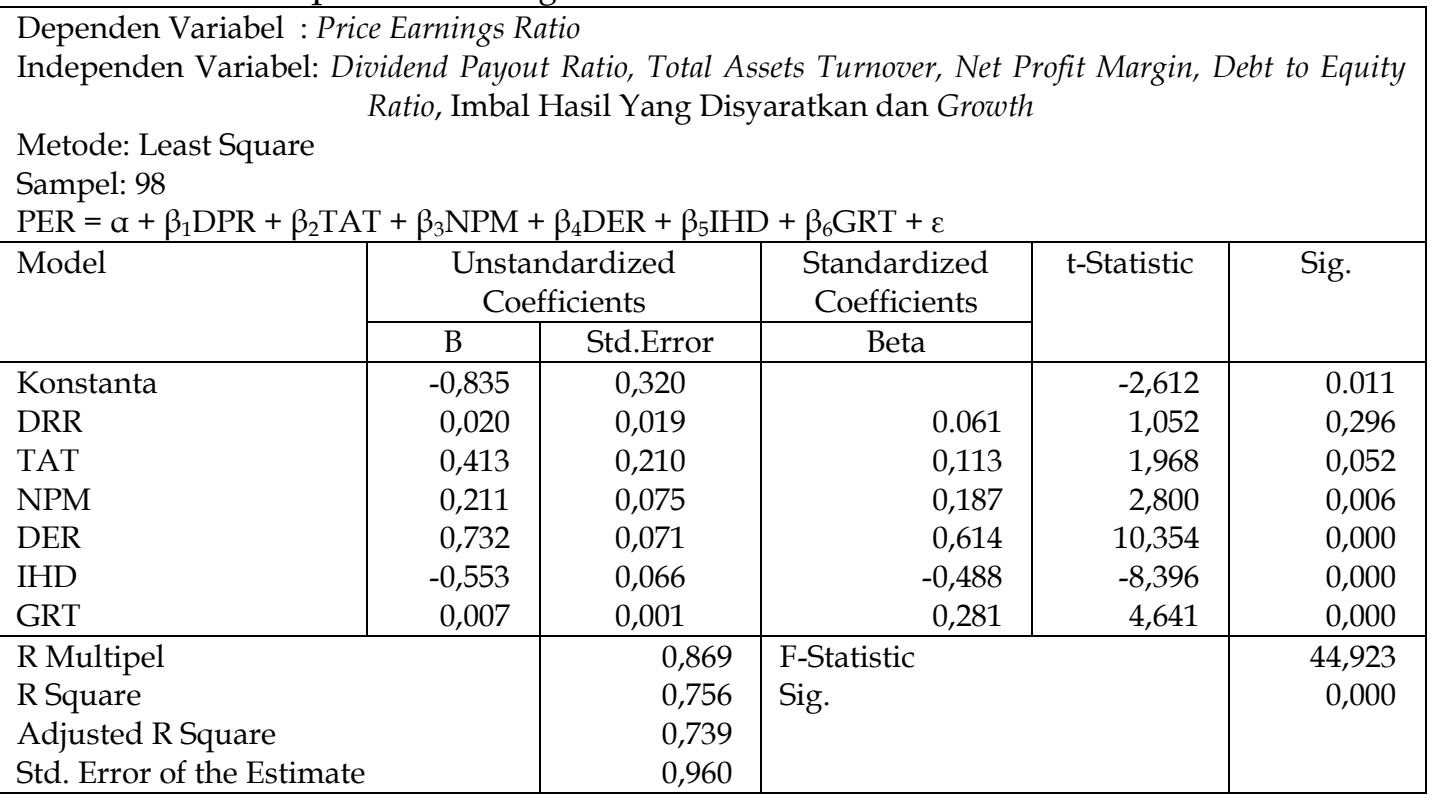

Sumber: Hasil Olahan Data Penelitian dengan Mempergunakan Program SPSS Version 18.

Berdasarkan Tabel 9 tersebut di atas, dapat dikemukakan bahwa nilai koefisien determinan sebesar 75,6 persen dengan nilai F-statistik adalah 44,923, dan probabilitas sebesar 0,000. Selanjutnya, nilai koefisien regressi standardisasi variabel dividend payout ratio (DPR) sebesar 0,061 dengan nilai t-satistik adalah 1,052 dan probabilitas sebesar 0,296. Oleh karenanya dapat dikemukakan bahwa dividend payout ratio (DPR) tidak berpengaruh terhadap price earnings ratio (PER). Nilai koefisien regressi standardisasi variabel total assets turnover (TAT) sebesar 0,113 dengan nilai t-satistik adalah 1,968 dan probabilitas sebesar 0,052. Dengan demikian dapat dikemukakan bahwa total assets turnover (TAT) berpengaruh positip dan signifikan terhadap price earnings ratio (PER). Nilai koefisien regressi standardisasi variabel net profit margin (NPM) sebesar 0,181 dengan nilai t-statistik adalah 2,800 dan probabilitas sebesar 0,006. Dengan demikian dapat dikemukakan bahwa net profit margin (NPM) berpengaruh positip dan signifikan terhadap price earnings ratio (PER). Nilai koefisien standardisasi variabel debt to equity ratio (DER) sebesar 0,614 dengan nilai t-statistik sebesar 10,354 dan probabilitas adalah 0,000. Oleh karenanya dapat dikemukakan bahwa debt to equity ratio berpengaruh positip dan signifikan terhadap price earnings ratio (PER). Nilai koefisien standardisasi variabel imbal hasil yang disyaratkan (IHD) sebesar -0,488 dengan nilai t-satistik adalah -8,396 dan probabilitas sebesar 0,000. Oleh karena itu, dapat dikemukakan bahwa imbal hasil yang disyaratkan (IHD) berpengaruh negatip dan signifikan terhadap price earnings ratio (PER). Nilai koefisien standardisasi variabel growth (GRT) adalah 0,281 dengan nilai t-statistik sebesar 4,641 dan probabilitas sebesar 0,000. Oleh karena itu dapat dikemukakan bahwa growth berpengaruh positip dan signifikan terhadap price earnings ratio (PER).

\section{Pembahasan}

Berdasarkan model-model yang telah dikemukakan bahwasanya nilai koefisien determinasi berada dalam kisaran 43,1 - 75,6 persen. Artinya, variabel-variabel yang menjadi 
determinan price earnings ratio (PER) mampu menjelaskan oleh variasi price earnings ratio (PER) sebesar 43,1 - 75,6 persen, sementara 24,4 - 56,9 persen lagi merupakan variabel yang tidak termasuk dalam model. Dengan demikian dapat juga dikemukakan bahwa model yang dibangun cukup baik dalam menjelaskan determinan price earnings ratio (PER).

Selanjutnya, masing-masing variabel yang dipergunakan dalam menjelaskan price earnings ratio akan dijelaskan dengan memperhatikan koefisien arah dan tingkat signifikansinya.

Variabel retention ratio (RR) memiliki koefisien arah negatip. Artinya, jika laba perusahaan semakin besar direinvestasikan dalam perusahaan mengakibatkan price earnings ratio (PER) semakin rendah, hanya saja tidak signifikan secara statistik.

Variabel return on equity (ROE) memiliki koefisien arah yang positip dan signifikan secara statistik. Artinya, setiap kenaikan return on equity (ROE) mengakibatkan price earnings ratio (PER) juga naik. Oleh karenanya, investor yang berkeinginan untuk melakukan investasi dalam bentuk saham di pasar modal, dapat mempergunakan return on equity (ROE) sebagai salah satu informasi dalam membuat keputusan. Selanjutnya, bagi perusahaan, diharapkan melakukan usaha sedemikian rupa untuk meningkatkan return on equity (ROE) sebab berdampak positip dalam memaksimumkan kemakmuran pemilik perusahaan. Artinya, efisiensi dan efektifitas penggunaan ekuitas akan meningkatkan return on equity (ROE).

Variabel imbal hasil yang diharapkan (IHD) memiliki koefisien arah yang negatip dan signifikan secara statistik. Artinya, setiap kenaikan imbal hasil yang diharapkan (IHD) mengakibatkan price earnings ratio (PER) turun. Oleh karenanya, investor yang berkeinginan untuk melakukan investasi dalam bentuk saham di pasar modal, dapat mempergunakan imbal hasil yang diharapkan (IHD) sebagai salah satu informasi dalam membuat keputusan. Selanjutnya, bagi perusahaan, diharapkan melakukan usaha sedemikian rupa untuk menurunkan imbal hasil yang diharapkan (IHD) sebab berdampak negatip dalam memaksimumkan kemakmuran pemilik perusahaan. Artinya, komponen risiko perlu diturunkan dalam menurunkan imbal hasil yang diharapkan (IHD).

Variabel growth (GRT) memiliki koefisien arah yang positip dan signifikan secara statistik. Artinya, setiap kenaikan growth (GRT) mengakibatkan price earnings ratio (PER) juga naik. Oleh karenanya, investor yang berkeinginan untuk melakukan investasi dalam bentuk saham di pasar modal, dapat mempergunakan growth (GRT) sebagai salah satu informasi dalam membuat keputusan. Selanjutnya, bagi perusahaan, diharapkan melakukan usaha sedemikian rupa untuk menaikkan growth (GRT) sebab berdampak positip dalam memaksimumkan kemakmuran pemilik perusahaan. Artinya, melakukan investasi yang memiliki NPV positip dalam menaikkan growth (GRT).

Variabel dividend payout ratio (DPR) memiliki koefisien arah yang positip dan signifikan secara statistik. Artinya, setiap kenaikan dividend payout ratio (DPR) mengakibatkan price earnings ratio (PER) juga naik. Oleh karenanya, investor yang berkeinginan untuk melakukan investasi dalam bentuk saham di pasar modal, dapat mempergunakan dividend payout ratio (DPR) sebagai salah satu informasi dalam membuat keputusan. Selanjutnya, bagi perusahaan, diharapkan melakukan usaha sedemikian rupa untuk menaikkan dividend payout ratio (DPR) sebab berdampak positip dalam memaksimumkan kemakmuran pemilik perusahaan. Artinya, meningkatkan efisiensi dan meningkatkan omset penjualan dalam rangka menaikkan dividend payout ratio (DPR).

Variabel total assets turnover (TAT) memiliki koefisien arah yang positip dan signifikan secara statistik. Artinya, setiap kenaikan total assets turnover (TAT) mengakibatkan price earnings ratio (PER) juga naik. Oleh karenanya, investor yang berkeinginan untuk melakukan investasi 
dalam bentuk saham di pasar modal, dapat mempergunakan total assets turnover (TAT) sebagai salah satu informasi dalam membuat keputusan. Selanjutnya, bagi perusahaan, diharapkan melakukan usaha sedemikian rupa untuk menaikkan total assets turnover (TAT) sebab berdampak positip dalam memaksimumkan kemakmuran pemilik perusahaan. Artinya, meningkatkan efisiensi dan efektivitas manajemen harta dalam meningkatkan omset penjualan dalam rangka menaikkan total assets turnover (TAT).

Variabel net profit margin (NPM) memiliki koefisien arah yang positip dan signifikan secara statistik. Artinya, setiap kenaikan net profit margin (NPM) mengakibatkan price earnings ratio (PER) juga naik. Oleh karenanya, investor yang berkeinginan untuk melakukan investasi dalam bentuk saham di pasar modal, dapat mempergunakan net profit margin (NPM) sebagai salah satu informasi dalam membuat keputusan. Selanjutnya, bagi perusahaan, diharapkan melakukan usaha sedemikian rupa untuk menaikkan net profit margin (NPM) sebab berdampak positip dalam memaksimumkan kemakmuran pemilik perusahaan. Artinya, meningkatkan efisiensi dan menghindari pemborosan serta meningkatkan omset penjualan dalam rangka menaikkan net profit margin (NPM).

Variabel debt to equity ratio (DER) memiliki koefisien arah yang positip dan signifikan secara statistik. Artinya, setiap kenaikan debt to equity ratio (DER) mengakibatkan price earnings ratio (PER) juga naik. Oleh karenanya, investor yang berkeinginan untuk melakukan investasi dalam bentuk saham di pasar modal, dapat mempergunakan debt to equity ratio (DER) sebagai salah satu informasi dalam membuat keputusan. Selanjutnya, bagi perusahaan, diharapkan melakukan usaha sedemikian rupa untuk menaikkan debt to equity ratio (DER) sebab berdampak positip dalam memaksimumkan kemakmuran pemilik perusahaan. Artinya, penambahan utang dilakukan dalam membiayai harta perusahaan jika biaya utang tersebut tentu lebih rendah dari basic earnings power perusahaan. Artinya, hasil penelitian ini mendukung teori MM murni.

Hasil penelitian juga menunjukkan bahwa koefisien regressi debt to equity ratio (DER) memiliki koefisien regressi distandardisasi yang lebih besar di antara koefisien regressi distandardisasi variabel bebas lainnya. Kondisi ini menggambarkan bahwa determinan yang dominan dalam menjelaskan piece earnings ratio (PER) adalah debt to equity ratio (DER).

\section{Kesimpulan}

\section{KESIMPULAN DAN SARAN}

Berdasarkan hasil penelitian dan pembahasan yang telah dikemukakan, berikut ini dibuat beberapa kesimpulan sebagai berikut.

Pertama, return on equity, imbal hasil yang diharapkan atau tingkat kapitalisasi, growth, dividend payout ratio, total assets turnover, net profit margin, dan debt to equity ratio merupakan determinan price earnings ratio.

Kedua, return on equity berpengaruh positip dan signifikan terhadap price earnings ratio, imbal hasil yang diharapkan atau tingkat kapitalisasi berpengaruh negatip dan signifikan terhadap price earnings ratio, growth berpengaruh positip dan signifikan terhadap price earnings ratio, dividend payout ratio berpengaruh positip dan signifikan terhadap price earnings ratio, total assets turnover berpengaruh positip dan signifikan terhadap price earnings ratio, net profit margin berpengaruh positip dan signifikan terhadap price earnings ratio, dan debt to equity ratio berpengaruh positip dan signifikan terhadap price earnings ratio.

Ketiga, debt to equity ratio merupakan determinan dominan dari price earnings ratio.

Keempat, variasi price earnings ratio mampu dijelaskan oleh variasi variabel bebasnya sebesar 43,1 - 75,6 persen. 


\section{Saran}

Berdasarkan hasil penelitian dan pembahasan yang telah dikemukakan, berikut ini dibuat beberapa saran sebagai berikut.

Pertama, perlu melakukan penelitian lanjutan dengan memasukkan faktor fundamental lainnya, seperti kondisi makro ekonomi dan industri.

Kedua, hasil penelitian ini dapat dipergunakan oleh investor dalam membuiat keputusan berinvestasi di pasar modal, serta bagi perusahaan dalam rangka meningkatkan nilai perusahaan.

\section{DAFTAR PUSTAKA}

Amling, Frederick, 1989. Investment an Introduction to Analysis and Management, Sixth Edition, New Jersey: Prentice Hall.

Bodie, Zvi, Alex Kane and Alan J. Markus, 2005. Investment, Sixth Edition, McGraw-Hill Companies.

Bolten, Steven E., 1976. Managerial Finance : Principles of Corporate Finance, Third Edition, Singapore, McGraw Hill Book Co.

Francis, Jack Clark, 1988. Management of Investment, Second Edition, Singapore, McGraw Hill Book Co.

Indriantoro, Nur dan Bambang Supomo, 1999. Metodologi Penelitian Bisnis untuk Akuntansi dan Manajemen, Edisi Pertama, BPFE, Yogyakarta.

Institute for Economic and Financial Research, 2013, Indonesian Capital Market Directory, Jakarta.

Philippatos, George C., 1973. Financial Management : Theory and Techniques, New Jersey : Holden - Day Inc.

Sihombing, Binsar, 2008, Analisis Pengaruh Faktor-Faktor Fundamental Terhadap Harga Saham Perusahaan Manufaktur Yang Terdaftar Di Bursa Efek Jakarta, Majalah Ilmiah Media Unika 20, 37 - 62.

Silalahi, Donalson, 1992, Beberapa faktor Yang Mempengaruhi Perubahan harga Saham (Studi Pada Pasar Modal Di Indonesia), Majalah Ilmiah Media Unika 3, 11 - 29.

Sulistiawan, Dedhy dan Liliana, 2007, Analisis Teknikal Modern Pada Perdagangan sekuritas, Cara Praktis memprediksi Pergerakan Harga saham \& Sekuritas Lainnya. Penerbit andi Yogyakarta.

Weston, J. Fred and Thomas E. Copeland, 1986. Managerial finance, Eight Edition, Japan : CBS International Edition. 